\title{
SPECTROSCOPY IN THE ANALYSIS OF BACTERIAL AND EUKARYOTIC CELL FOOTPRINTS ON IMPLANT SURFACES
}

\author{
E. Kaivosoja ${ }^{1,2}$, S. Virtanen ${ }^{3}$, R. Rautemaa ${ }^{4,5,6,7}$, R. Lappalainen ${ }^{8}$ and Y.T. Konttinen ${ }^{1,9,10, *}$ \\ ${ }^{1}$ Department of Medicine, Institute of Clinical Medicine, Helsinki University Central Hospital, Finland \\ ${ }^{2}$ Department of Electronics, School of Electrical Engineering, Aalto University, Finland ${ }^{3}$ Department of Materials Science \\ and Engineering, Chair for Surface Science and Corrosion, Friedrich-Alexander-University of Erlangen-Nüremberg, Germany \\ ${ }^{4}$ Department of Bacteriology and Immunology, Haartman Institute, University of Helsinki, Finland \\ ${ }^{5}$ Department of Oral Medicine, Institute of Dentistry, University of Helsinki ${ }^{6}$ Department of Oral and Maxillofacial Diseases, \\ Helsinki University Central Hospital, Finland \\ ${ }^{7}$ The University of Manchester, Manchester Academic Health Science Centre, School of Translational Medicine and University \\ Hospital of South Manchester, UK \\ ${ }^{8}$ Department of Applied Physics, Kuopio Campus, University of Eastern Finland, Kuopio, Finland \\ ${ }^{9}$ ORTON Orthopaedic Hospital of the ORTON Foundation, Helsinki, Finland \\ ${ }^{10} \mathrm{COX}$ A Hospital for Joint Replacement, Tampere, Finland
}

\begin{abstract}
We tested the suitability of two spectroscopic methods, $\mathrm{x}$-ray photoelectron spectroscopy (XPS) and time of flight secondary ion mass spectrometry (ToF-SIMS), in the recognition of bacterial and eukaryotic cell footprints on implant surfaces. Human mesenchymal stem cells (MSCs) and Staphylococcus aureus were cultured on sample surfaces and detached using trypsin. Scanning electron microscopy confirmed that the processed surfaces did not contain any human or microbial cells. The footprints were then analysed using XPS and ToF-SIMS. XPS results showed no significant differences between the footprints, but principal component analysis of the ToF-SIMS data enabled clear separation of MSC-footprints from the $S$. aureus and co-culture footprints $(p<0.03)$. ToF-SIMS also demonstrated 'race for the surface' between proteins, which suggest surface charge (zeta-potential) dependent protein adsorption. ToF-SIMS differentiated eukaryotic and bacterial footprints and has potential for post-hoc detection of implant-related infections based on the typical ToF-SIMS spectra.
\end{abstract}

Keywords: Bacterial infection; time of flight secondary ion mass spectrometry; $\mathrm{x}$-ray photoelectron spectroscopy.

*Address for correspondence:

Y.T. Konttinen

PO Box 70

00029 HUS, Finland

FAX Number: +358-9-191 25218

E-mail: yrjo.konttinen@helsinki.fi

\section{Introduction}

Bacterial infections remain an important cause of failure of many types of implants (Darouiche, 2001; Darouiche, 2004). Infected abiotic and immune-compromised implant surfaces and materials act as bacterial growth substrates and reservoirs, impairing implant function, propagating local spreading of the infection into surrounding tissues and haematogenic "metastatic" infections into distant sites. Recognition of the colonisation of the implant surface by bacteria remains an important clinical and academic issue.

Reliable recognition of bacterial infection in implantrelated infections is challenging. The classical diagnostic method is bacterial culture of the periprostetic tissues and fluids. However, recognition of the differences between planktonic and biofilm bacteria has disclosed many important differences of relevance in this context between these two microbial states. Biofilm bacteria are not easily accessible to naive and immune host defence cells or soluble factors, such as complement or antibiotics (Costerton et al., 1999). Further, dormant pathogens embedded in the biofilm and adhering to the implant surface can be difficult to detach and grow in bacterial culture (Gristina and Costerton, 1985; Tunney et al., 1999). Therefore, different approaches have been developed to diminish false negative culture results, e.g. multiple sampling from the surface of the implant (direct swabs) and sonication of the implant to detach and disperse bacteria from implant surface to culture (Neut et al., 2003; Marculescu et al., 2005; Panousis et al., 2005; Trampuz and Widmer, 2006; Trampuz and Zimmerli, 2006; Zimmerli, 2006). None of these methods is perfect and the frequent use of antibiotics before sample collection further increases the risk for false-negative culture results (Darouiche, 2001; Berbari et al., 2007; Malekzadeh et al., 2010), but false-positive culture results are also possible, usually as a result of contamination during sample processing and culture.

Eukaryotic cells and bacteria produce various molecular components destined for extracellular deposition, which they excrete outside the cell. Eukaryotic cells synthesise components of extracellular matrix in their cytoplasm and secrete them via exocytosis. 
Furthermore, adherent cells produce special adhesion organs known as focal adhesions (Konttinen et al., 2011). Also, bacteria excrete polymeric compounds, which form their extracellular polymeric substance (EPS), so called bacterial "slime" (Donlan, 2002). EPS is a polymeric conglomerate composed of extracellular DNA, proteins, and polysaccharides. We hypothesise that the molecular composition of the mammalian ECM and bacterial EPS differ to such an extent that modern and sensitive spectroscopic methods would enable their specific identification from cell-free footprints left on an implant surface after an effective removal of whole live and dead eukaryotic and bacterial cells. Because the cells, which produced them, are already gone, these acellular remnants left on their former growth substrate surface are hereafter referred to as "footprints". The aim of the work was to test two spectroscopic methods that might be useful for demonstration of previous bacterial colonisation, but in the absence of bacteria, and enable its differentiation from footprints left by human cells. Due to their role in implantrelated infections (Cunningham et al., 2004; Trampuz and Zimmerli, 2006; Sohail et al., 2007), Staphylococcus aureus was selected as the model bacterium, and due to the role of mesenchymal stromal cells in healing of periimplant tissue and implant integration (Chatterjea et al., 2010), MSC was selected as the model eukaryotic cell for these first "proof of the principle" studies. Titanium is a commonly used biomaterial and was therefore included in the study. Diamond like carbon (DLC) was selected in the study because of its anti-fouling properties (Page et al., 2009; Goto and Brunette, 2010). Based on our previous experiments, relatively weak footprints were expected because $S$. aureus and MSCs did not attach and spread on DLC surfaces as well as e.g. on cytocompatible Ti surface; for $S$. aureus $23 \%$ coverage was reached on Ti vs. $0.4 \%$ coverage on DLC (Levon et al., 2010). For MSCs 83\% coverage was reached on Ti vs. $73 \%$ coverage on DLC (Myllymaa et al., 2010). If it is possible to see differences in the bacterial, eukaryotic and joint (co-culture) footprints on DLC, it is very likely that the footprint analysis is rather sensitive and easily discloses differences in the footprints in other materials as well. Patterned materials were included to have a type of internal control (in the background material) and as a preliminary pilot to check if this study design could be used to demonstrate the 'race for the surface' phenomenon of bacterial and host cells (Gristina, 1987).

In recent years, ToF-SIMS has been employed for studying the surface of protein-based materials. Adsorbed protein films have been characterised (Lhoest et al., 2001; Wagner et al., 2001; Wagner et al., 2002a; Wagner et al., 2002b; Wagner et al., 2003a; Wagner et al., 2003b; Bernsmann et al., 2008; Tyler et al., 2011) and even conformational changes (Xia et al., 2002) and denaturation of proteins (Killian et al., 2011) can be detected with ToFSIMS. Surface characterisations of extracellular matrix scaffolds (Canavan et al., 2007, Brown et al., 2010; Barnes et al., 2011) and insulin and albumin coated surfaces have been published (Henry and Bertrand, 2009). In the field of microbiology, ToF-SIMS has been applied to imaging colonies of microbes (Tyler et al., 2006, Esquenazi et al.,
2009), to characterise intact, individual bacterial spores in 3D (Ghosal et al., 2008) and to detect antibiotics within intact bacterial colony biofilms (Gasper et al., 2008). Some previous experiments have applied TOF-SIMS to cellular material and have successfully discriminated between different yeast strains (Jungnickel et al., 2005) and different breast cancer cell types (Kulp et al., 2006). Here, we extend these earlier findings further, attempting to distinguish between two different cell types based on their footprints, following detachment of the cells from their matrix, rather than trying to distinguish the cells themselves. Although it has been shown before that after cell sheet detachment, traces of amino acids are found on the culture substrate (Canavan et al., 2005a; Canavan et al., 2006), identification of different cells based only on these cellular footprints on biomaterial has never been attempted before by ToF-SIMS experiments.

\section{Materials and Methods}

\section{Sample fabrication}

DLC and titanium were deposited on silicon surfaces, both as planar coating and patterned coating. The samples contained regularly spaced $75 \mu \mathrm{m} \times 75 \mu \mathrm{m}$ squares covered with titanium or DLC squares with the distance of $100 \mu \mathrm{m}$. Patterning was produced using photolithography and liftoff techniques.

Thin films of titanium were magnetron sputtered (Stiletto Serie ST20, AJA International Inc., North Scituate, MA, USA) in argon plasma with high purity ( $99.9 \%$ or better) target materials (Goodfellow Metals, Huntingdon, UK). An acceleration voltage of 400-500 V, a chamber pressure of $3-4 \times 10^{-4}$ mbar and a deposition time of $5 \mathrm{~min}$ were used to deposit approximately $200 \mathrm{~nm}$ thick films.

DLC coatings were deposited using ultra-short pulsed laser deposition (USPLD) technique. Just before deposition, the sample surfaces were gently cleaned using $\mathrm{Ar}^{+}$ion sputtering (SAM-7KV, Minsk, Belarus). For deposition, we used a new type of mode-locked fibre laser (Corelase, Tampere, Finland) and Coldab ${ }^{\mathrm{TM}}$ deposition technology developed by Picodeon (Helsinki, Finland) to achieve optimal laser parameters in USPLD (Myllymaa et al., 2009). The maximum average power was $20 \mathrm{~W}$ at $4 \mathrm{MHz}$ which results in a $5 \mu \mathrm{J}$ pulse energy. The pulse length was 20 ps. High purity graphite was used as the target for DLC deposition. The deposition parameters were adjusted to obtain stable plasma and to deposit about a $150 \mathrm{~nm}$ thick layer.

After deposition, the patterns on wafers were revealed by immersion in a mr-Rem 660 resist remover (Microresist Technology, Berlin, Germany) in an ultrasonic bath for a few minutes. Wafers were finally cut to $10 \mathrm{~mm}$ x $10 \mathrm{~mm}$ samples before sonication for a few minutes in $7 \mathrm{x}$ detergent (OneMed, Vantaa, Finland), ethanol and deionised water to remove organic residues and silicon dust from dicing.

\section{Sample sterilisation}

Samples were immersed in Petri dishes for $30 \mathrm{~min}$ in $70 \%$ ethanol, which was removed by pouring and evaporation before packaging in sterile bags and sterilisation using 
$26 \pm 3 \mathrm{kGy}$ gamma irradiation. The source was calibrated according to ASTM 1026-95 Standard Method for Absorbed Gamma Radiation Dose in the Fricke Dosimeter.

\section{Measurement of zeta-potential}

Zeta-potentials were measured using an electrokinetic analyser (SurPASS, Anton Paar, Graz, Austria) in $\mathrm{pH} 7.1 \pm 0.1$ in $1 \mathrm{mM} \mathrm{KCl}$. The samples were measured in duplicates (i.e., two pairs) using an adjustable gap cell on which the samples were mounted and the measurements were repeated three times for each pair. The zeta-potential was evaluated from streaming current measurements according to the Helmholtz-Smoluchowski equation:

$$
\zeta=\frac{d l}{d P} \times \frac{\eta}{\varepsilon \times \varepsilon_{o}} \times \frac{L}{A}
$$

Where $\zeta$ is the zeta-potential; $d l / d P$ is the slope of streaming current $v s$. different pressure; $\eta$ is the electrolyte viscosity; $\varepsilon$ is the permittivity; $\varepsilon_{0}$ is the dielectric coefficient of electrolyte; and $L$ is the length of streaming channel and $A$ is its cross-section. Error estimation was based on the standard error of the mean.

\section{Cell cultures}

Human bone marrow-derived passage-5 MSC (PoieticsTM, Lonza, Basel, Switzerland) were cultured on $10 \mathrm{~cm}$ Petri dishes (Corning, Corning, NY, USA) using Lonza Mesenchymal Stem Growth Medium (MSCGM) containing Mesenchymal Cell Growth Supplement, L-Glutamine and GA-1000 (Gentamicin/Amphotericin-B). The cells were cultured at $37{ }^{\circ} \mathrm{C}$ in humid $5 \% \mathrm{CO}_{2}$-in-air. The cell monolayer was washed with phosphate buffered $140 \mathrm{mM}$ saline (PBS, pH 7.4) and the cells were detached using $2.5 \mathrm{mg} / \mathrm{mL}$ trypsin in PBS-EDTA $\left(0.05 \mathrm{~mL} / \mathrm{cm}^{2}\right)$ at room temperature for $5 \mathrm{~min}$. An equal volume of temperature equilibrated MSCGM was added. The suspension was transferred to a Falcon tube and trypsin was removed by centrifuging the cells at $600 \mathrm{~g}$ for $5 \mathrm{~min}$. Cells were resuspended in culture medium and seeded onto the pre wetted biomaterial surfaces at 6000 cells per $\mathrm{cm}^{2}$ density. The cells were cultured for 6 days (near confluence). TCtreated polystyrene 12-well microplates (Corning) were used in all experiments. A similar protocol was followed when the control samples without cells were prepared.

\section{Bacterial cultures}

A biofilm producing strain of $S$. aureus S-15981, kindly provided by Dr. Lasa (Valle et al., 2003), was cultured on blood agar for $24 \mathrm{~h}$ at $37^{\circ} \mathrm{C}$ under aerobic conditions. Twenty colony forming units (CFU) were suspended into $10 \mathrm{~mL}$ tryptic soy broth (TSB) and cultured for $24 \mathrm{~h}$ at $37{ }^{\circ} \mathrm{C}$ in a $15 \mathrm{~mL}$ tube (with static agitation). This suspension was re-suspended and $1 \mathrm{~mL}$ was inoculated into $9 \mathrm{~mL}$ of TSB and incubated for $18 \mathrm{~h}$ at $37^{\circ} \mathrm{C}$. Thereafter, the concentration was adjusted to $6 \times 10^{8} \mathrm{CFU} / \mathrm{mL}$ using a McFarland standard and verified by serial dilution plating. Biomaterial samples placed in the wells of pre-sterilised, polystyrene, flat-bottomed, 12-well microplates (Corning) were pre-wetted with TSB and covered with $1 \mathrm{~mL}$ of the microbial solution and incubated for $24 \mathrm{~h}$ at $37^{\circ} \mathrm{C}$. Then, medium was aspirated and non-adherent cells removed by thoroughly washing the biofilms three times in sterile PBS, covered with $1 \mathrm{~mL}$ of TSB and incubated for another $24 \mathrm{~h}$ at $37^{\circ} \mathrm{C}$. During the incubation samples were agitated gently using a GrantBioPMS 100 microplate shaker. Noninfected wells (TSB alone) were also included to serve as negative controls.

\section{Co-cultures}

Two types of co-cultures were prepared in MSCGM without antibiotics. In the first set-up, MSCs were suspended in MSCGM and seeded on the biomaterial surfaces placed in 12-well microplates at 6000 cells per $\mathrm{cm}^{2}$ density and cultured for $48 \mathrm{~h}$ at $37{ }^{\circ} \mathrm{C}$ in humid $5 \%$ $\mathrm{CO}_{2}$-in-air. After $48 \mathrm{~h}$, the surfaces were covered with S-15981 Staphylococcus solution at concentration of 6 $\times 10^{8} \mathrm{CFU} / \mathrm{mL}$ in MSCGM and incubated for 48 hours at $37{ }^{\circ} \mathrm{C}$. After $24 \mathrm{~h}$ the suspension was refreshed with $500 \mu \mathrm{L}$ of MSCGM.

In the second set-up, both MSCs and S-15981 were suspended in MSCGM using similar seeding densities (6000 MSCs per $\left.\mathrm{cm}^{2}\right)$ and concentration $\left(6 \times 10^{8} \mathrm{CFU} /\right.$ $\mathrm{mL}$ ) as above. Biomaterial surfaces were placed in 12-well microplates, followed by addition of $1 \mathrm{~mL}$ of the mixed Staphylococcus and MSC solution. These co-cultures were incubated for $96 \mathrm{~h}$ at $37^{\circ} \mathrm{C}$. Refreshing was done every $24 \mathrm{~h}$, by replacing $500 \mu \mathrm{L}$ of the culture solution with fresh MSCGM.

\section{Viability in co-cutures}

Bacterial viability in MSCGM was confirmed with staining using Live/Dead BacLight ${ }^{\mathrm{TM}}$ kit (Molecular Probes/Life Technologies, Gaithersburg, MD, USA), which was applied according to manufacturer's instructions and analysed using fluorescence microscopy.

To assess the amount of biomass in a biofilm, $S$. aureus was cultured in MSCGM and in TSB on 24-well plates for $96 \mathrm{~h}$, washed with PBS, dried for $30 \mathrm{~min}$ at room temperature and stained in $200 \mu \mathrm{L}$ of $0.3 \%$ crystal violet (Reagena Ltd., Toivala, Finland) for $5 \mathrm{~min}$. Samples were washed gently in running water and destained in $200 \mu \mathrm{L}$ of absolute ethanol, which was transferred to a clean 96well plate. Absorbance at 544 was measured with Plate CHAMELEON V (Chameleon Systems, Ruislip, UK) plate reader.

To test the viability of MSCs in co-cultures, samples were prepared on coverslips using the same experimental settings as described above. After the co-culture incubation, Live \& Dead staining was performed using the Live/ Dead Viability/Cytotoxicity Kit for mammalian cells (Molecular Probes). Samples were washed with PBS, stained with MSC-optimised staining solution $(8 \mu \mathrm{M}$ calcein acetomethoxy and $2 \mu \mathrm{M}$ Ethidium Homodimer-1) for 40 min, washed with PBS and mounted in Vectashield (Vector Laboratories, Peterborough, UK).

Live \& Dead staining was observed using Leica DM6000 B/M Research Microscope equipped with a DFC365FX camera (Leica Microsystems, Wetzlar, Germany). 


\section{Surface cleaning}

The seeding density and culture times for both MSCs and $S$. aureus were selected so that the culture was near confluence before surface cleaning. Surfaces were washed three times in PBS. Cells and bacteria were trypsinised (1:10 trypsin in PBS-EDTA) 5 min at $37^{\circ} \mathrm{C}$, after which the trypsin was neutralised with equal amount of trypsin neutralisation solution (PromoCell, Heidelberg, Germany). Samples were washed three times with $\mathrm{dH}_{2} \mathrm{O}$ and sterilised in abs. ethanol. The samples were soaked in $\mathrm{dH}_{2} \mathrm{O}$ for at least $24 \mathrm{~h}$ to reduce free ions remaining from the buffer after which the liquid on the sample was removed using the $\mathrm{N}_{2}$ gas.

\section{Scanning electron microscopy (SEM)}

To ensure that the surfaces were well cleaned from cells and bacteria the samples were imaged with a Hitachi (Tokyo, Japan) SEM FE 4800 field emission scanning electron microscope (FE-SEM) without any additional surface treatments at an accelerating voltage of $10 \mathrm{kV}$.

\section{X-ray photoelectron spectroscopy (XPS)}

XPS measurements were conducted on X-ray photoelectron spectrometer (PHI 5600) using monochromated Al Ka radiation $(1486.6 \mathrm{eV}, 300 \mathrm{~W})$ for excitation. The spectra of the elements were determined at a pass energy of $23.5 \mathrm{eV}$ and a total energy resolution of $<0.4 \mathrm{eV}$, and values were recorded every $0.1 \mathrm{eV}$ and at a takeoff angle of $45^{\circ}$ with respect to the surface normal. XPS was performed only for planar titanium and DLC surfaces. To interpret XPS data, linear least square fit of Gaussian functions were fitted to the high-resolution oxygen, nitrogen and carbon spectra (Matlab, Mathworks, Natick, MA, USA).

Time of flight secondary ion mass spectrometry (ToFSIMS)

Positive and negative static ToF-SIMS measurements were performed using a ToF-SIMS V spectrometer (ION TOF, Münster, Germany). The samples were irradiated with a pulsed $25 \mathrm{keV} \mathrm{Bi}^{+}$liquid-metal ion beam. The beam was electrodynamically bunched down to $25 \mathrm{~ns}$ to increase the mass resolution and rastered over a $500 \times 500 \mu \mathrm{m}^{2}$ area. For patterned samples measurements were carried out separately from pattern and background, from an area of approx. $70 \times 70 \mu \mathrm{m}^{2}$. The primary ion dose density (PIDD) was kept at approximately $5 \times 10^{11}$ ions $\mathrm{x} \mathrm{cm}^{-2}$, ensuring static conditions. Signals were identified using the accurate mass as well as their isotopic pattern. In this article, only the positive ToF-SIMS spectra are presented because they contain a greater amount of information regarding our area of interest.

Based on the preliminary analysis of the ToF-SIMS spectra, 11 components that showed difference between MSC and $S$. aureus samples were selected for ToF-SIMS imaging. The components were $\mathrm{m} / \mathrm{z} 39 \mathrm{~K}, 70 \mathrm{C}_{4} \mathrm{H}_{8} \mathrm{~N}, 73$ $\mathrm{C}_{4} \mathrm{H}_{10} \mathrm{~N}, 74 \mathrm{C}_{3} \mathrm{H}_{8} \mathrm{NO}, 86 \mathrm{C}_{5} \mathrm{H}_{12} \mathrm{~N}, 91 \mathrm{C}_{7} \mathrm{H}_{7}, 101 \mathrm{C}_{4} \mathrm{H}_{9} \mathrm{~N}_{2} \mathrm{O}$, $110 \mathrm{C}_{5} \mathrm{H}_{8} \mathrm{~N}_{3}, 120 \mathrm{C}_{8} \mathrm{H}_{10} \mathrm{~N}, 130 \mathrm{C}_{9} \mathrm{H}_{8} \mathrm{~N}$ and $136 \mathrm{C}_{8} \mathrm{H}_{10} \mathrm{~N}$.

\section{Principal component analysis (PCA)}

First, all spectra were mean-centred prior to principal component analysis. A limited peak set was constructed
Table 1: List of characteristic secondary ions fragments cleaved off from amino acids for mass spectrometric analysis.

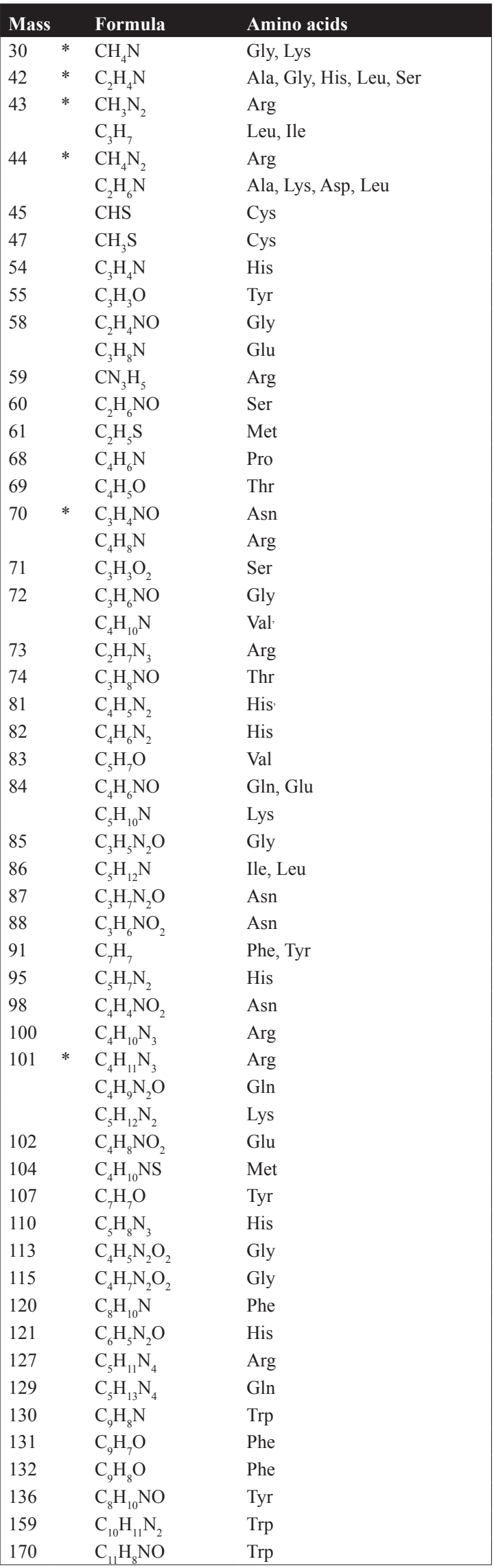

* not included in the analysis. 
to compare the positive ToF-SIMS spectra from all sample types. This limited peak set was constructed using unique amino acid fragmentation patterns of ToF-SIMS data previously identified for characterising proteins. Table 1 shows the selected peaks together with the amino acid they are characteristic for and the proportion of that amino acid (Samuel et al., 2001; Wagner and Castner, 2001; Canavan et al., 2006; Henry and Bertrand, 2009). Peaks that can originate from several different amino acids (marked with a star in Table 1) were not included in the analysis. The peak areas for each spectrum were then normalised to the intensity of the sum of the selected peaks to account for fluctuations in secondary ion yield between different spectra. Then, the data of MSCGM was subtracted from MSC-data and co-culture data and the data of tryptic soy broth was subtracted from $S$. aureus data. PCA was used to analyse the ToF-SIMS spectra (Matlab, MathWorks) of MSC and bacteria footprint. Coefficients obtained from PCA were applied then also to the co-culture data. To further elucidate differences between the groups, the data were analysed with Mann-Whitney U-test (SPSS, Chicago, IL, USA).

Patterned DLC-samples were not included in the PCA analysis as our previous study showed that after $90 \mathrm{~min}$ long adhesion experiment only $0.38 \%$ of the patterns and $0.40 \%$ of the background was covered with $S$. aureus and thus hardly any footprint can be expected (Levon et al., 2010).

\section{Results}

\section{Zeta-potential}

DLC has the lowest zeta-potential $(-54.5 \pm 0.6 \mathrm{mV})$ and Ti the highest $(-40.9 \pm 0.9 \mathrm{mV})$ and $\mathrm{Si}$ an intermediate $(-46.7 \pm 0.5 \mathrm{mV})$ zeta-potential.

\section{SEM}

SEM images showed that surfaces were well cleaned from cells and bacteria (Fig. 1).

\footnotetext{
Viability

As a control, it was important to show that S-15981 Staphylococci grow effectively and produce EPS, both in this MSCGM medium and with this culture time. This was confirmed by Live \& Dead staining (not shown), which showed that Staphylococci grew effectively. The volume of EPS produced was measured by using absorbance of crystal violet to the biofilm formed. These experiments indicated that the amount of biomass of the biofilm produced in MSCGM during this culture time was similar to that produced in the TSB culture medium (absorbance at 544 was $1.4 \pm 0.3$ in TSB, $1.3 \pm 0.3$ in MSCGM and $0.3 \pm 0.02$ for negative controls).

In co-culture type 1, where $S$. aureus and MSCs were added simultaneously, almost all MSCs were detached from the surface after $96 \mathrm{~h}$ of co-culture. In co-culture type 2 some MSCs were still viable (not shown).
}

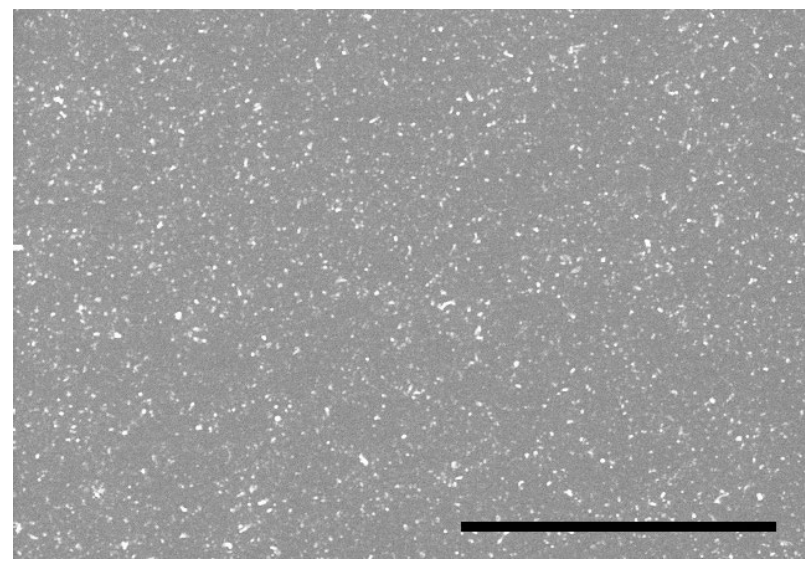

Fig. 1. Scanning electron microscopy image of the surface showing that after the procedure used for the detachment of the bacterial and mammalian cells from the implant surface, no bacterial and eukaryotic cells remain attached to surface. Scale bar is $10 \mu \mathrm{m}$.

\section{XPS}

The quantitative results from XPS analysis are shown in Table 2. In general, the XPS spectra exhibited peaks from oxygen, carbon and nitrogen. In addition, the Ti-samples naturally had the spectra of Ti2p.

The hydrocarbon (C-C and C-H; Fig. 2) peak is located at $284.2 \mathrm{eV}$, the ether and alcohol contributions $(\mathrm{C}-\mathrm{O}-\mathrm{C}$ and $\mathrm{C}-\mathrm{O}-\mathrm{H})$ at $286.0 \mathrm{eV}$, acetal carbon $(\mathrm{O}-\mathrm{C}-\mathrm{O})$ at $288.3 \mathrm{eV}$ and the ester group at $288.8 \mathrm{eV}(\mathrm{C}-\mathrm{O}-\mathrm{C}=\mathrm{O}$ and $\mathrm{O}-\mathrm{C}=\mathrm{O})$.

The spectra of N1s exhibited a peak with a binding energy of about $400 \mathrm{eV}$, indicating that nitrogen was present in the organic matrix, probably as amino groups, most likely originating from amino acids.

The high oxygen peak originates from oxidation of the surface and the shoulder appearing at a binding energy 1.4-1.6 eV higher than the main $\mathrm{O} 1 \mathrm{~s}$ peak originates from ether (C-O-C), alcohol (C-O-H) and ketone oxygen $(\mathrm{C}=\mathrm{O})$. The small shoulder at $533.7 \mathrm{eV}$ indicates carbonyl- and ether-type oxygen in ester $(\mathrm{O}=\mathrm{C}-\mathrm{O}-\mathrm{C})$.

Only a few differences were observed between Tisamples. MSC samples have relatively higher amount

Table 2: The relative atomic concentrations of carbon, nitrogen, oxygen, and titanium are presented from x-ray photoelectron spectroscopy measurement.

Mesenchymal stem cell (MSC), growth media (GM), tryptic soy broth (TSB).

\begin{tabular}{|lcccc|} 
Sample & C1s & N1s & O1s & Ti2p \\
\hline Ti MSC & 48.03 & 4.35 & 35.45 & 12.17 \\
Ti MSC-GM & 44.64 & 7.42 & 36.35 & 11.59 \\
Ti $S$. aureus & 51.24 & 6.92 & 32.93 & 8.90 \\
Ti TSB & 43.29 & 6.31 & 37.41 & 13.00 \\
DLC MSC & 74.63 & 8.81 & 16.55 & \\
DLC MSC-GM & 75.92 & 8.39 & 15.70 & \\
DLC S. aureus & 74.57 & 9.19 & 16.24 & \\
DLC TSB & 73.78 & 7.19 & 19.03 & \\
\hline
\end{tabular}



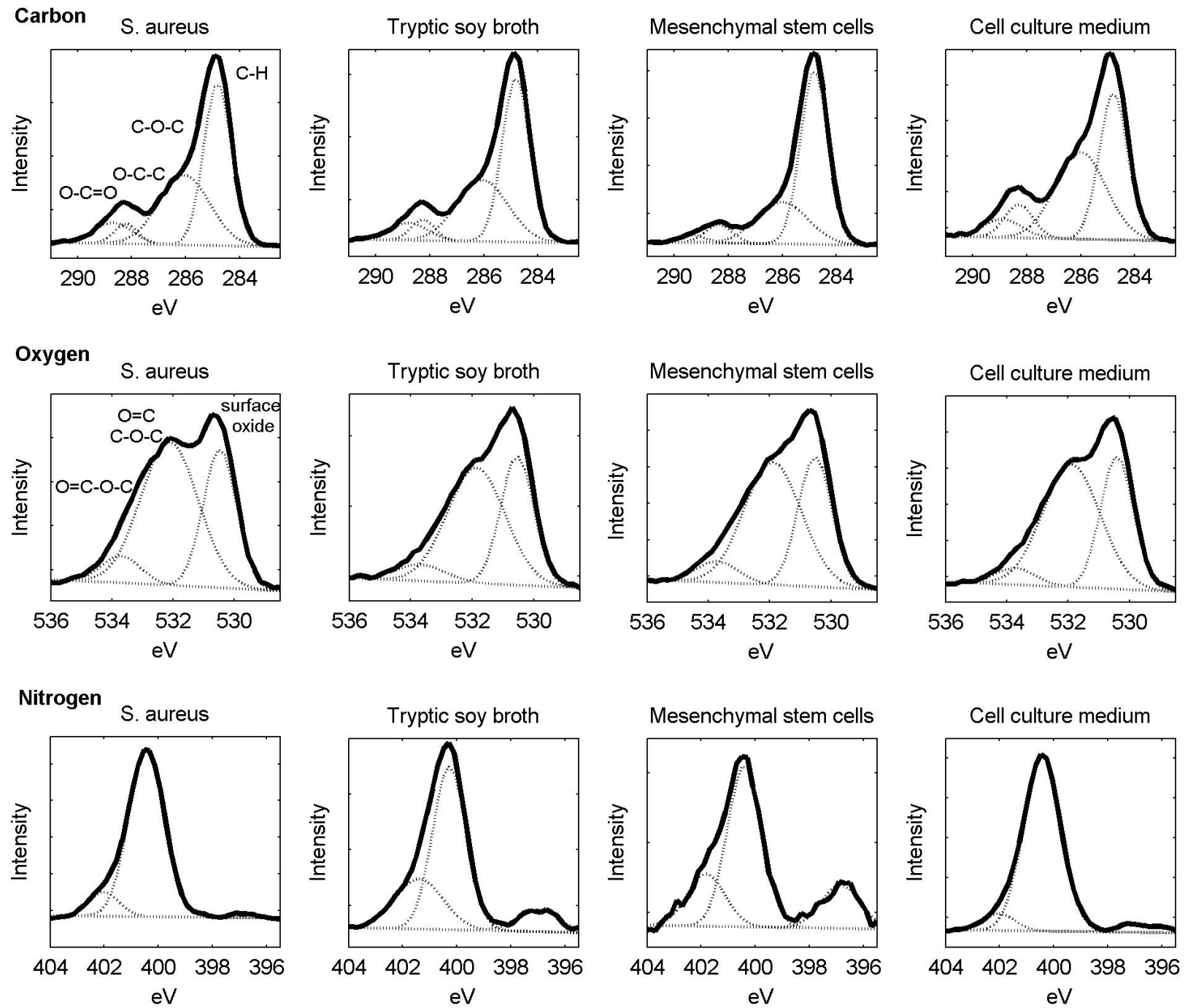

Fig. 2. X-ray photoelectron spectroscopy of carbon, oxygen and nitrogen on Ti surfaces subjected to Staphylococcus aureus and mesenchymal stem cell cultures and their media.

of hydrocarbon $(68.5 \%$ of $\mathrm{C} 1$ peak while others have $<56.5 \%)$, lower amount of carbon in ester groups $(1.4 \%$ of $\mathrm{C} 1$ compared to $>4.0 \%$ of other samples) and higher amount of energy at $397 \mathrm{eV}$ compared other samples ( $16.2 \%$ of $\mathrm{N} 1 \mathrm{~s}$ compared to $>8.6 \%$ of other samples). On $S$. aureus samples the second $\mathrm{O} 1$ peak is a little shifted being $1.6 \mathrm{eV}$ higher than the main $\mathrm{O} 1 \mathrm{~s}$ peak $(532.1 \mathrm{eV}$ compared to $531.9 \mathrm{eV}$ of the other samples). This indicates that $S$. aureus sample surface contains more ether and alcohol oxygens than ketone oxygens when compared to other samples. However, these differences are not sufficient for separating $S$. aureus samples from MSC samples.

\section{ToF-SIMS}

The PCA of the ToF-SIMS data allowed clear overall separation $(p<0.03)$ of $S$. aureus samples and co-culture samples from MSC-samples (Fig. 3A; representative samples). The differences were predominantly observed in principal component (PC) 1, which accounted for $66 \%$ of the statistical separation of the total variance between all samples. Logically, the PCA values of co-cultures locate between the values of pure MSC-samples and pure $S$. aureus samples. Furthermore, the co-culture type 1 (started with MSC culture) was further away from $S$. aureus than the co-culture type 2 (to which MSC and Staphylococci were added simultaneously), with one exception. Titanium patterns showed a much stronger $S$. aureus footprint in co-cultures than in pure $S$. aureus culture.

It was observed that the peaks at $\mathrm{m} / \mathrm{z} 72\left(\mathrm{C}_{3} \mathrm{H}_{6} \mathrm{NO}\right.$ glycine, $\mathrm{C}_{4} \mathrm{H}_{10} \mathrm{~N}$ valine $), 84\left(\mathrm{C}_{5} \mathrm{H}_{10} \mathrm{~N}\right.$ lysine, $\mathrm{C}_{4} \mathrm{H}_{6} \mathrm{NO}$ glutamine / glutamic acid) and $86\left(\mathrm{C}_{5} \mathrm{H}_{12} \mathrm{~N}\right.$, leucine / isoleucine) accounted for most of the loading on the $S$. aureus site of the PC 1 axis while peaks at $\mathrm{m} / \mathrm{z} 45,47$ (CHS, $\mathrm{CH}_{3} \mathrm{~S}$ cysteine $)$ and $81\left(\mathrm{C}_{4} \mathrm{H}_{5} \mathrm{~N}_{2}\right.$ histidine $)$ accounted for most of the loading on the side of the PC 1 axis attributed to the MSC-samples (Fig. 3B). The MSCs expressed more histidine than $S$. aureus and culture on the patterned Ti surfaces showed a clear structure of the main histidine component (110; Fig. 4A).

In PC 2, which accounted for $19 \%$ of the statistical separation of the total variance between all samples, the only component accounting over $20 \%$ weight was $\mathrm{m} / \mathrm{z} 45$ 

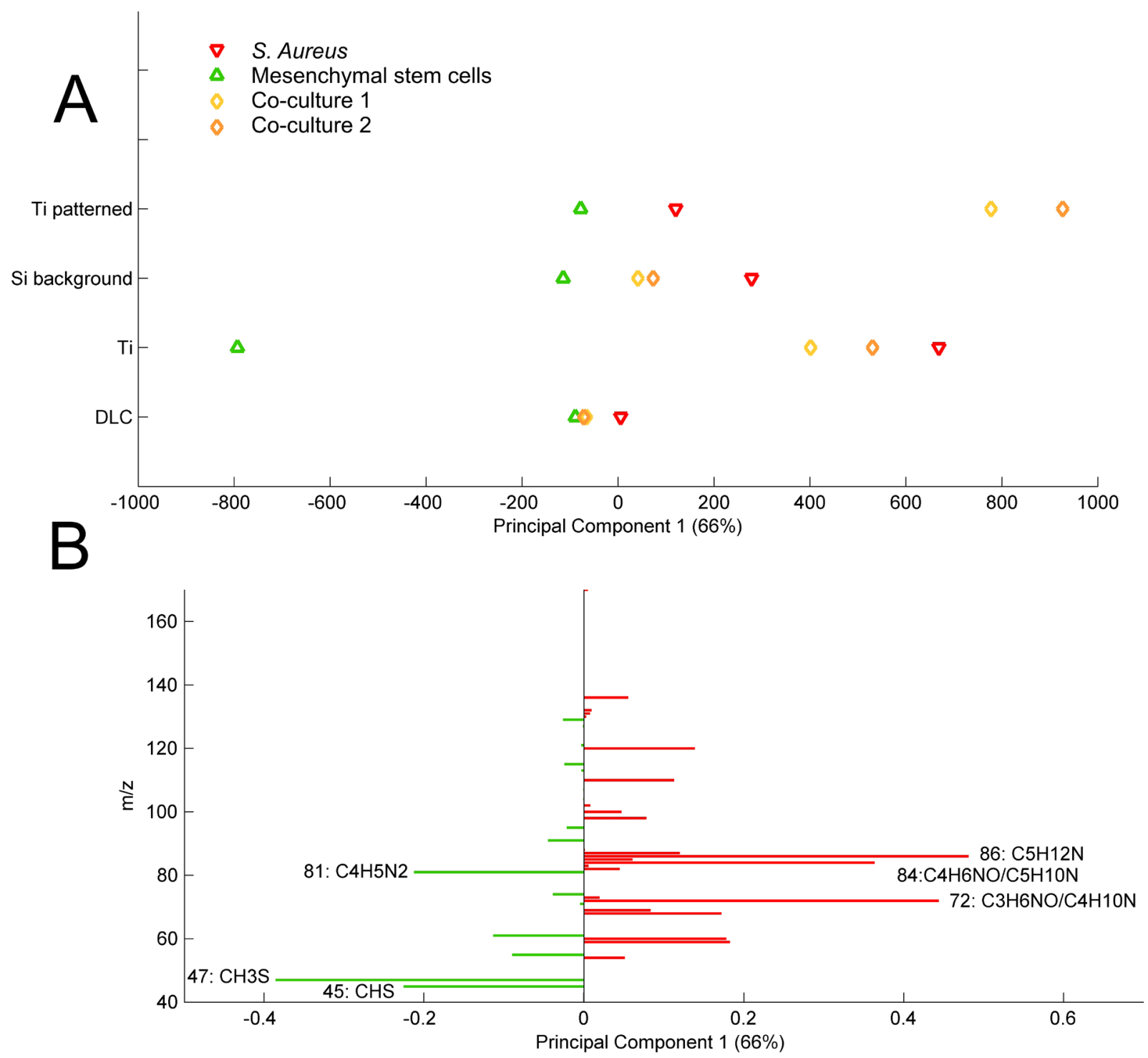

Fig. 3. Results of principal component analysis (PCA). (A) Scores of PCA. The Staphylococcus aureus and co-culture footprint are clearly separated from the mesenchymal stem cell footprint. In co-culture 1, MSCs were cultured on the surfaces $48 \mathrm{~h}$ prior to seeding of $S$. aureus. In co-culture 2, MSCs and $S$. aureus were seeded at the same time. Measurements were performed on patterned titanium on silicon background and on pure titanium and diamond like carbon (DLC) surfaces. (B) Loads of PCA. Components counting over $20 \%$ loads are named. It was observed that the peaks at $\mathrm{m} / \mathrm{z} 72\left(\mathrm{C}_{3} \mathrm{H}_{6} \mathrm{NO}, \mathrm{C}_{4} \mathrm{H}_{10} \mathrm{~N}\right), 84\left(\mathrm{C}_{5} \mathrm{H}_{10} \mathrm{~N}, \mathrm{C}_{4} \mathrm{H}_{6} \mathrm{NO}\right)$ and $86\left(\mathrm{C}_{5} \mathrm{H}_{12} \mathrm{~N}\right)$ accounted for most of the loading on the $S$. aureus site of the PC1 axis while peaks at $\mathrm{m} / \mathrm{z} 45(\mathrm{CHS}), 47\left(\mathrm{CH}_{3} \mathrm{~S}\right)$ and $81\left(\mathrm{C}_{4} \mathrm{H}_{5} \mathrm{~N}_{2}\right.$, histidine) accounted for most of the loading on the side of the PC 1 axis attributed to the MSC-samples.
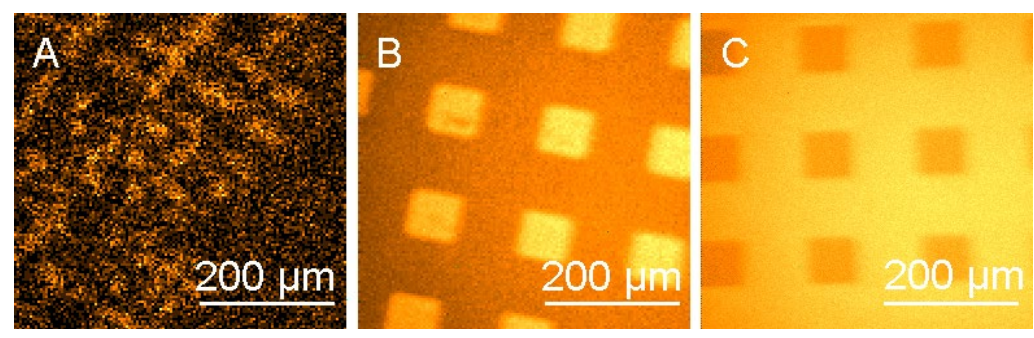

Fig. 4. Adsorption visualised with a time of flight secondary ion mass spectrometer. (A) After mesenchymal stem cell culture component 110 (histidine) shows a clear structure on titanium. (B) Titanium patterns adsorbs more molecules than silicon background (total ion count) but (C) DLC patterns adsorb less molecules than silicon background (total ion count). 


\section{Tryptic soy broth}

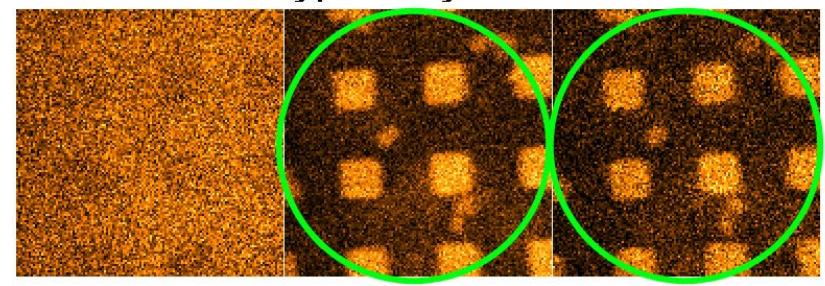

$\mathrm{m} / \mathrm{z} 39 \mathrm{~K}$

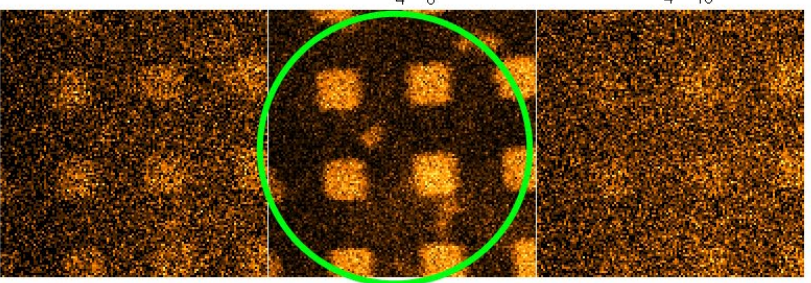

$\mathrm{m} / \mathrm{z} 74 \mathrm{C}_{3} \mathrm{H}_{8} \mathrm{NO} \quad \mathrm{m} / \mathrm{z} 86 \mathrm{C}_{5} \mathrm{H}_{12} \mathrm{~N}$

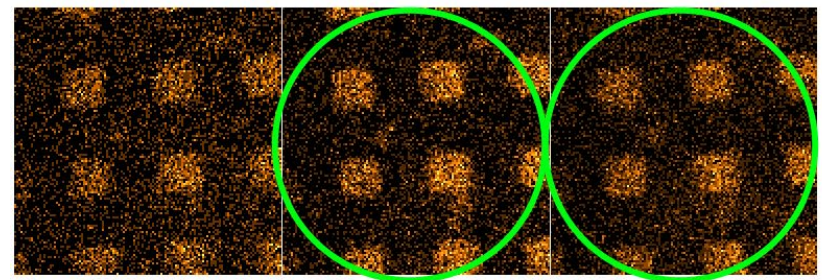

$\mathrm{m} / \mathrm{z} 101 \mathrm{C}_{4} \mathrm{H}_{9} \mathrm{~N}_{2} \mathrm{O} \quad \mathrm{m} / \mathrm{z} 110 \mathrm{C}_{5} \mathrm{H}_{8} \mathrm{~N}_{3} \quad \mathrm{~m} / \mathrm{z} 120 \mathrm{C}_{8} \mathrm{H}_{10} \mathrm{~N}$

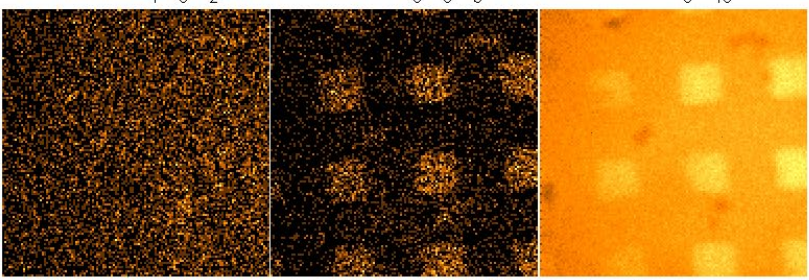

$\mathrm{m} / \mathrm{z} 130 \mathrm{C}_{9} \mathrm{H}_{8} \mathrm{~N}$

$\mathrm{m} / \mathrm{z} 136 \mathrm{C}_{8} \mathrm{H}_{10} \mathrm{NO}$ sum of the rest

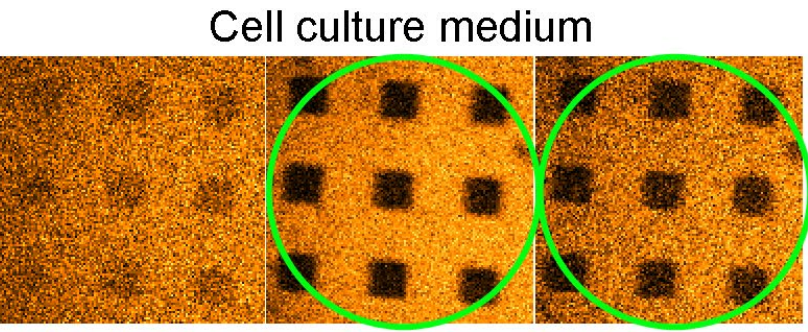

$\mathrm{m} / \mathrm{Z} 70 \mathrm{C}_{4} \mathrm{H}_{8} \mathrm{~N}$

$\mathrm{m} / \mathrm{z} 72 \mathrm{C}_{4} \mathrm{H}_{10} \mathrm{~N}$

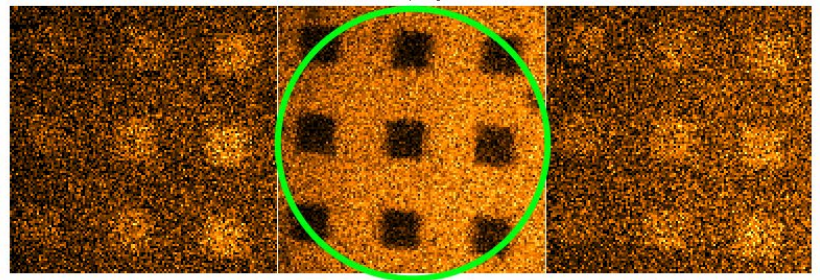

$\mathrm{m} / \mathrm{z} 74 \mathrm{C}_{3} \mathrm{H}_{8} \mathrm{NO}$

$\mathrm{m} / \mathrm{z} 86 \mathrm{C}_{5} \mathrm{H}_{12} \mathrm{~N}$

$\mathrm{m} / \mathrm{z} 91 \mathrm{C}_{7} \mathrm{H}_{7}$

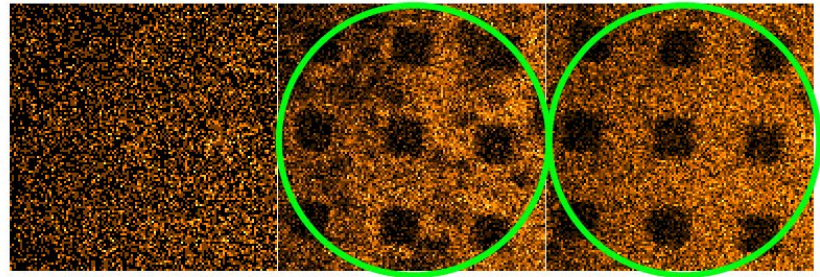

$\mathrm{m} / \mathrm{z} 101 \mathrm{C}_{4} \mathrm{H}_{9} \mathrm{~N}_{2} \mathrm{O} \quad \mathrm{m} / \mathrm{z} 110 \mathrm{C}_{5} \mathrm{H}_{8} \mathrm{~N}_{3} \quad \mathrm{~m} / \mathrm{z} 120 \mathrm{C}_{8} \mathrm{H}_{10} \mathrm{~N}$

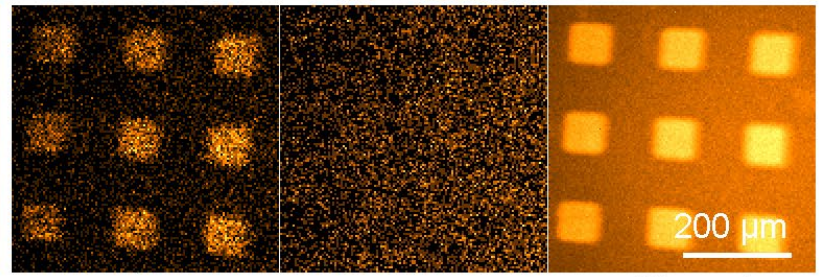

$\mathrm{m} / \mathrm{z} 130 \mathrm{C}_{9} \mathrm{H}_{8} \mathrm{~N}$

$\mathrm{m} / \mathrm{z} 136 \mathrm{C}_{8} \mathrm{H}_{10} \mathrm{NO}$ sum of the rest

Fig. 5. Adsorption of tryptic soy broth and mesenchymal stem cell culture medium on patterned titanium sample visualised with a time of flight secondary ion mass spectrometer. Differences between the two media are circled.

(CHS, $93 \%$ ) and it was predominantly associated with differences between MSC sample and $S$. aureus sample on silicon background, accounting for most of the $\mathrm{m} / \mathrm{z} 45$ (CHS) loading to the MSC site of the PC 2 axis (not shown).

ToF-SIMS results demonstrated interesting 'race for the surface' (Gristina, 1987) phenomenon on patterned Ti-samples. The cell culture media mass components $70\left(\mathrm{C}_{3} \mathrm{H}_{4} \mathrm{NO}, \mathrm{C}_{4} \mathrm{H}_{8} \mathrm{~N}\right), 72\left(\mathrm{C}_{3} \mathrm{H}_{6} \mathrm{NO}, \mathrm{C}_{4} \mathrm{H}_{10} \mathrm{~N}\right), 86$ $\left(\mathrm{C}_{5} \mathrm{H}_{12} \mathrm{~N}\right), 110\left(\mathrm{C}_{5} \mathrm{H}_{8} \mathrm{~N}_{3}\right)$ and $120\left(\mathrm{C}_{6} \mathrm{H}_{5} \mathrm{~N}_{2} \mathrm{O}\right)$ preferred the Si-background over the Ti-patterns. The same mass components of bacterial culture medium TSB showed the opposite preference, preferring the Ti-patterns over the $\mathrm{Si}$ background (Fig. 5). On the patterned DLC-samples the selected components of TSB showed similar adsorption as on the patterned Ti-samples except for the mass component 91, which showed the opposite preference; it clearly preferred the Si-background over the DLC-patterns (Fig. 6). However, the cell culture medium showed different adsorption preference on the patterned DLC-samples from that on the patterned Ti-samples. From the components that were imaged this opposite preference can be seen for components $70,72,86,91\left(\mathrm{C}_{7} \mathrm{H}_{7}\right), 110,120$ and 130
(Fig. 6). Intriguingly, the total ion preference on patterned Ti-samples was on the Ti-patterns but on the patterned DLC-samples the ions preferred the Si-background (Fig. $4 \mathrm{~B}, \mathrm{C})$.

The surfaces exposed to cell and bacteria showed similar but more blurred preferences as their culture media. The exception was that on patterned Ti-samples the preference of potassium (39) changed and histidine (the histidine-derived mass component $\mathrm{m} / \mathrm{z} 110 \mathrm{C}_{5} \mathrm{H}_{8} \mathrm{~N}_{3}$ ) showed a clear structure (Fig. 4A).

\section{Discussion}

We hypothesised that XPS spectra, obtained by focused $\mathrm{X}$-ray irradiation of the footprints on the implant surface and analysis of the number and kinetic energy of the detached (emitted) photoelectrons, could be used in the recognition of cellular footprints. XPS has been earlier used to detect differences in the amounts of calcium and phosphorous as a sign of mineralisation on the culture substrate before and after osteoblast culture (Mustafa et al., 2002). XPS is also suitable for recognition of different 

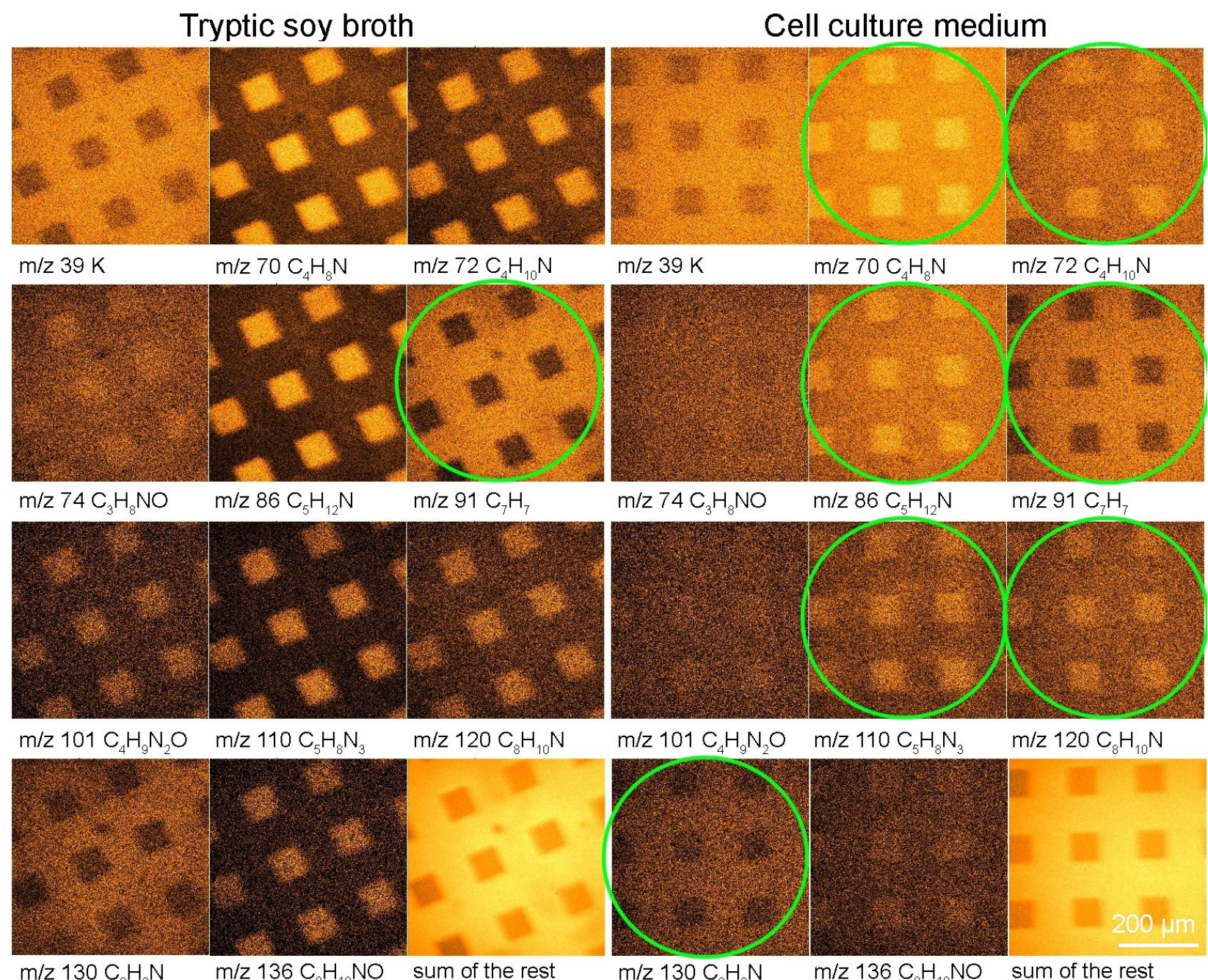

$\mathrm{m} / \mathrm{z} 130 \mathrm{C}_{9} \mathrm{H}_{8} \mathrm{~N}$

$\mathrm{m} / \mathrm{z} 136 \mathrm{C}_{8} \mathrm{H}_{10} \mathrm{NO}$ sum of the rest

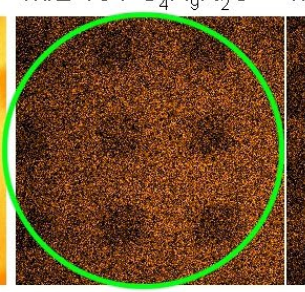

$\mathrm{m} / \mathrm{z} 130 \mathrm{C}_{9} \mathrm{H}_{8} \mathrm{~N}$

$\mathrm{m} / \mathrm{z} 136 \mathrm{C}_{8} \mathrm{H}_{10} \mathrm{NO}$ sum of the rest

Fig. 6. Adsorption of tryptic soy broth and mesenchymal stem cell culture medium on patterned diamond like carbon sample visualised with a time of flight secondary ion mass spectrometer. The differences of adsorption, compared to patterned titanium sample, are circled.

monosaccharides, disaccharides, and polysaccharide (Stevens and Schroeder, 2009). However, in our study, with a much more complex ECM and EPS as the study objects, only minor differences were observed between MSC- and S. aureus-culture samples so that a reliable separation of them was impossible. This could be expected due to the relatively non-descript nature of XPS compared to SIMS analysis of protein-adhered surfaces, as has been welldescribed in the literature (Wagner and Castner, 2001; Canavan et al., 2005b).

ToF-SIMS is obtained by focusing a pulsed primary ion beam onto the footprints on the implant surface and analysis of the number and mass of the detached secondary ions, as well as for a reconstruction of a topographical map on their localisation on the surface of the target of the ion beam, that is, of the implant and footprint surface. In contrast to XPS, this method seems to have potential for separation of mammalian and bacterial footprints. Some previous experiments have applied TOF-SIMS for cellular material and have successfully discriminated, for example, between different yeast strains (Jungnickel et al., 2005), different breast cancer cell types (Kulp et al., 2006) and living and dead bacterial cells (Tyler et al., 2006). These studies, however, are significantly different from ours as they studied the actual cellular materials whereas we used TOF-SIMS to discriminate the infected surfaces from the non-infected surfaces after careful cleaning and removal of the cellular material (cells) from these surfaces. Not quite surprisingly, the footprints produced were affected by the substrate material used for culture. This might have contributed to the difference observed between MSC- and S. aureus-produced ECM and ESP remnants, respectively.

It has been earlier shown that both MSCs and $S$. aureus spread better on Ti surfaces than on DLC surfaces. In 5-day MSC cultures on patterned surfaces, $82.7 \%$ of Ti- and $72.7 \%$ of DLC-patterns were covered by MSCs (Myllymaa et al., 2010). In $16 \mathrm{~h} \mathrm{~S}$. aureus cultures, $100 \%$ of the planar Ti but only $81.05 \%$ of the planar DLC surface was covered by bacteria ( $p<0.001)$ (Levón et al, unpublished results). This better adherence and growth of both types of cells on 
the "sticky" titanium may in part explain why the MSC and $S$. aureus footprints were more easily differentiated on Ti than on DLC samples.

Another potential explanation for the differences in the TOF-SIMS footprints between Ti and DLC surfaces is that the Ti surface binds more proteins and amino acids than the Si-background and that the DLC surface binds less of these components than the Si-background (Fig. 4). This was demonstrated by the ToF-SIMS images of patterned Ti and DLC samples, where the total ion count was significantly higher on the Ti-patterns than on the Si-background, whereas on the DLC-patterns the total ion count was lower than on the Si-background. The differential binding of proteins and amino acid on these two surfaces may, for some compounds, result in part from the differences of the zeta-potential values of these samples. It has been earlier demonstrated that the lower the absolute value of the zetapotential (measured in $0.001 \mathrm{M} \mathrm{KCl}$ ) of the surface is, the lower is the adsorption of serum proteins on it (Cai et al., 2006). However, these studies were conducted on surfaces, which had zeta-potentials within a relatively narrow range of only -12 to $0 \mathrm{mV}$. Indeed, typically the streaming current measurements are performed in $\mathrm{KCl}$ because use of culture media would contaminate the electrokinetic analyser used to measure zeta potential. Zeta-potential of the samples would certainly be different e.g. in the cell culture media. Therefore, correlation between protein adsorption and zetapotential value measured in $\mathrm{KCl}$ is disputed and, according to the above mentioned work, zeta potentials measured in $1 \mathrm{mM} \mathrm{KCl}$ only reflect the protein binding capacity of the test surfaces. Evidence has been recently presented that a parabolic relationship exists between the protein adsorption and zeta-potential when a much wider zeta-potential range is taken into consideration (Shin et al., 2008; Kaivosoja et al., 2011).

In co-culture type 1 , where $S$. aureus and MSCs were added simultaneously, there were no longer MSCs present after $96 \mathrm{~h}$ incubation. In co-culture type 2, where MSCs were first allowed to adhered and grow for $48 \mathrm{~h}$ before the addition of $S$. aureus, there were some viable and adherent cells left on the culture substrate. Although the conditions were not optimal for co-habiting the sample surface, they simulate the situation in implant-related infections well. Presence of adhering bacteria, which produce biofilm and exotoxins, diminishes the substrate area covered by eukaryotic cells (Saldarriaga Fernández et al., 2011a; Saldarriaga Fernández et al., 2011b). Even though most of the MSCs had detached from the surface at $48 \mathrm{~h}$, they had left their footprint on the surface on which they had 'raced for the surface' with bacteria, and this was what we aimed for with these co-culture experiments. Non-optimised conditions may lead to stressed phenotypes causing deposition of stressed matrix proteins on surfaces, so it is possible that the differential in adhesion observed is a result caused by the stressed conditions. This does not undermine the hypothesis, but it may modify the outcome observed. In patients the situation is somewhat different, because new cells can be continuously recruited to the implant surface. Bacterial growth on implant surface starts with low colony forming unit numbers and, because many implantrelated infections are haematogenous, the host cells have had time to establish themselves on the implant surface. More importantly, it was possible to find evidence for a previous growth of bacteria in form of clearly detectable bacterial footprints on these samples, which no longer contained any bacterial cells, only remnants of their EPS. The topographical ToF-SIMS maps show that the S. aureus footprints express more valine, lysine, glutamine, glutamic acid, leucine, isoleucine, tyrosine and tryptophan as well as less cysteine and histidine than the MSC footprints. However, care must be taken when assigning ToF-SIMS mass peaks exclusively to particular amino acids. This is particularly true for the small molecular mass components, such as $\mathrm{CH}_{4} \mathrm{~N}(\mathrm{~m} / \mathrm{z} 30)$ mass peaks, which can produce a very high signal from every amino acid. $\mathrm{C}_{9} \mathrm{H}_{8} \mathrm{~N}(\mathrm{~m} / \mathrm{z} 130)$ suggests the presence of tryptophan in the footprint, but forms also the $3^{\text {rd }}$ most abundant peak produced by glutamine (Kulp et al., 2006). Furthermore, the influence of the closest neighbouring molecules in the protein structures on the ion beam induced fragmentation of the amino acids is difficult to predict. In spite of some such difficulties in the exclusive identification of the molecular mass peaks produced, the main point is that the footprints of MSC and $S$. aureus samples can be separated from each other using these ToF-SIMS spectra. This separation was clear on sticky titanium surfaces, but was possible even on DLC surfaces that are considered to be antifouling.

The reason that ToF-SIMS shows much higher signals attributed to $S$. aureus on most surfaces is logically associated with the $S$. aureus dominance likely to be found in co-cultures and rapid killing of mammalian cells in these cultures, as well as consistent surface dominance of bacteria in such cultures. However, the question is not about the signal intensity but about the differential signals (marks, footprint) left by bacterial and eukaryotic cells, which could provide evidence of previous bacterial colonisation and biofilm formation of bacteria-free implant surfaces.

ToF-SIMS images demonstrated an interesting 'race for the surface' (Gristina, 1987; Santavirta et al., 1992) type of phenomenon on patterned Ti-samples for proteins. Binding of certain ToF-SIMS components, e.g. $\mathrm{m} / \mathrm{z}$ 70, 110 , of the MSCGM and TSB were different on similarly patterned Ti-samples. Pattern contrast observed with ToF-SIMS is a function of the types and thicknesses of proteins adsorbed from the different culture milieu (or locally produced by the cells attached to the surface), which is influenced by the substrate. The total (secondary) ion preference of both media was on the Ti-patterns on the patterned Ti-samples. Nonetheless, individual components show different preferences. Figure 5 demonstrated that components $\mathrm{m} / \mathrm{z} 70,72,86,110$ and 120 of TSB preferred Ti-patterns over Si-background, but the same components of MSCGM preferred Si-background. In conclusion, the MSC growth medium contains some components that occupy the more favourable $\mathrm{Ti}$ on patterned surfaces, so that no space remains for the competing components. These other components lost the 'race for the surface' (e.g., $\mathrm{m} / \mathrm{z}$ 70, 72, 86, 110 and 120) and were not found on the Ti on the patterned surfaces. This theory is supported by the finding that on the patterned DLC-samples (where the total ion preference was on Si-background) these very 
same components were again forced to attach on the less favourable surface, namely on the DLC on the patterned surfaces.

The 'race for the surface' phenomenon can partly explain why the $S$. aureus footprint produced in cocultures on titanium-patterns was in fact stronger than the footprint of pure $S$. aureus on titanium-patterns. Previous experiments have shown that $S$. aureus favours binding to Ti-patterns over the Si-background $(22.7 \%$ coverage on the Ti-patterns vs. only $0.7 \%$ coverage on the Si-background (Levon et al., 2010)) whereas the difference for the MSCs is much lower ( $31 \%$ coverage on Ti-patterns vs. $24 \%$ coverage on Si-background (Myllymaa et al., 2010)).

The change in the preference for topological binding sites of potassium (39), on patterned Ti-samples, on a Sibackground before MSC-culture and on Ti-patterns after the MSC-culture indicates that MSCs prefer the Ti-patterns over the Si-background and leave a potassium-enriched footprint. Potassium is possibly derived from intracellular sources, where it is present at $135-150 \mathrm{mmol} / \mathrm{L}$ (Girgis, 2003), compared to only $3.5-5.5 \mathrm{mmol} / \mathrm{L}$ in often used washing buffers or normal plasma. This preference of MSCs for the Ti-patterns over the Si-background has also been demonstrated in our previous study, using SEM for tracing of the cells (Myllymaa et al., 2010). In the current study ToF-SIMS was used to trace the cellular footprints, which first become visible after the removal of the cells. Metal ions $\left(\mathrm{K}^{+}\right)$are not a quantitative indicator, since they could, in part, represent residuals from washing steps. However, they indicate a qualitative shift in their preferential binding after MSC culture and dominate the positive ion spectrum signal-noise when compared to the larger $\mathrm{m} / \mathrm{z}$ cations.

Use of trypsin to remove cells and bacteria from the model surfaces could remove certain protein-based and trypsin-sensitive adherent fragments that were not analysed using the surface methods employed. This pretreatment was anyway necessary, because in contrast to many previous cellular studies (which have focused on the cellular material on substrates), we focused on the ECM and EPS footprints left behind by eukaryotic and bacterial cells, respectively. The main point is that the footprints left by eukaryotic cells and bacterial cells were different, even though removal of cells by trypsin had caused some artefactual loss of the trypsin sensitive structures.

The substrate heavily influences the ion yields and fragmentation patterns detected by ToF-SIMS and therefore, fragment yields, ratios and efficiencies are likely to differ between DLC, titanium and various polymers or glasses. In spite of this, the footprint left by the eukaryotic cells and Staphylococci was different on all tested materials, suggesting that the footprints produced by the cells were specific to the type of cell which produced it. However, when the footprint produced by e.g., eukaryotic cells is compared between two or several different biomaterial substrates, the differences might be due to differences in the composition of the footprints, but might also in part reflect the dependence of the fragment yields on the different substrates, such as DLC or titanium.

Photolithography can leave residues on the surface, which cannot be detected by XPS but are detected by ToF-
SIMS (Dubey et al., 2009), which may act as a confounding factor. Therefore, the results are not quantitative, but should be considered as a comparison between different systems. For example, in the present work different cells were tested using similarly treated cell culture substrate materials. Cell exposed samples were compared to media exposed samples, in which experiments both of the media used were studied. It was found that the footprints of $S$. aureus were rather similar on all the studied substrates and different from the footprints left by MSCs. This emphasises the potential of ToF-SIMS for the detection of implant-related infections caused by bacteria, even in cases that are already culture negative.

These results are preliminary and the study needs to be continued by comparing actual implants, which have been removed from patients. This research provides a new option for retrospective studies, even in bacterial culture negative cases, if the surface of clinical implants eventually shows footprints of bacteria or eukaryotic cells, a new approach worth examining.

\section{Conclusions}

In contrast to XPS, ToF-SIMS is a potential tool for the differentiation of bacterial from eukaryotic acellular footprints and may have potential in the post-hoc diagnosis of colonisation, biofilm formation and implant-related infections even in culture negative cases. Furthermore, ToF-SIMS analysis seems to be suitable for analysis of biocompatibility of different growth substrates, because the type and extent of the footprint indicates how the cells adhered and thrived on the implant surface provided for growth. ToF-SIMS can even be used to study protein adsorption indirectly, because the ToF-SIMS experiments also showed the 'race for the surface' phenomenon in protein binding. This was clearly influenced by the zetapotential, both overall as well as exclusively for some components.

\section{Acknowledgements}

The authors acknowledge Helga Hildebrand for the ToFSIMS and XPS and Anja Friedrich for SEM investigations (Univ. Erlangen-Nürenberg), Veikko Sariola (Univ. Helsinki) for helping with data analysis, Sami Myllymaa and Hannu Korhonen (Univ. Eastern Finland) for fabricating some samples, Montserrat Español Pons and Maria-Pau Ginebra (the Department of Materials Science and Metallurgy, Technical University of Catalonia, Barcelona, Spain) for help with the zeta-potential measurements and the Laboratory of Radiochemistry, Department of Chemistry, University of Helsinki for sterilising samples. We acknowledge the support of Finska Läkaresällskapet, the National Doctoral Programme of Musculoskeletal Disorders and Biomaterials, Helsinki University Central Hospital evo grants, ORTON Invalid Foundation, Individualised Musculoskeletal Medicine project of the Danish Council of Strategic Research and Regenerative Medicine RNP of the European Science Foundation. 


\section{References}

Barnes CA, Brison J, Michel R, Brown BN, Castner DG, Badylak SF, Ratner BD (2011) The surface molecular functionality of decellularized extracellular matrices. Biomaterials 32: 137-143.

Berbari EF, Marculescu C, Sia I, Lahr BD, Hanssen AD, Steckelberg JM, Gullerud R, Osmon DR (2007) Culture-negative prosthetic joint infection. Clin Infect Dis 45: 1113-1119.

Bernsmann F, Lawrence N, Hannig M, Ziegler C, Gnaser H (2008) Protein films adsorbed on experimental dental materials: ToF-SIMS with multivariate data analysis. Anal Bioanal Chem 391: 545-554.

Brown BN, Barnes CA, Kasick RT, Michel R, Gilbert TW, Beer-Stolz D, Castner DG, Ratner BD, Badylak SF (2010) Surface characterization of extracellular matrix scaffolds. Biomaterials 31: 428-437.

Cai K, Frant M, Bossert J, Hildebrand G, Liefeith K, Jandt KD (2006) Surface functionalized titanium thin films: zeta-potential, protein adsorption and cell proliferation. Colloids Surf B Biointerfaces 50: 1-8.

Canavan HE, Cheng X, Graham DJ, Ratner BD, Castner DG (2005a) Surface characterization of the extracellular matrix remaining after cell detachment from a thermoresponsive polymer. Langmuir 21: 1949-1955.

Canavan HE, Cheng X, Graham DJ, Ratner BD, Castner DG (2005b) Cell sheet detachment affects the extracellular matrix: a surface science study comparing thermal liftoff, enzymatic, and mechanical methods. J Biomed Mater Res A 75: 1-13.

Canavan HE, Cheng X, Graham DJ, Ratner BD, Castner DG (2006) A plasma-deposited surface for cell sheet engineering: advantages over mechanical dissociation of cells. Plasma Process. Polym. 3: 516-523.

Canavan HE, Graham DJ, Cheng X, Ratner BD, Castner DG (2007) Comparison of native extracellular matrix with adsorbed protein films using secondary ion mass spectrometry. Langmuir 23: 50-56.

Chatterjea A, Meijer G, van Blitterswijk C, de Boer J (2010). Clinical application of human mesenchymal stromal cells for bone tissue engineering. Stem Cells Int 11: 215625 .

Costerton JW, Stewart PS, Greenberg EP (1999) Bacterial biofilms: a common cause of persistent infections. Science 284: 1318-1322.

Cunningham CD, Slattery HW, Luxford WM (2004) Postoperative infection in cochlear implant patients. Otolaryngol Head Neck Surg 131: 109-114.

Darouiche RO (2001) Device-associated infections: a macroproblem that starts with microadherence. Clin Infect Dis 33: $1567-1572$.

Darouiche RO (2004) Treatment of infections associated with surgical implants. N Engl J Med 350: 1422-1429.

Donlan RM (2002) Biofilms: microbial life on surfaces. Emerging Infect Dis 8: 881-890.

Dubey M, Emoto K, Cheng F, Gamble LJ, Takahashi H, Grainger DW, Castner DG (2009) Surface analysis of photolithographic patterns using ToF-SIMS and PCA. Surf Interface Anal 41: 645-652.
Esquenazi E, Yang YL, Watrous J, Gerwick WH, Dorrestein PC (2009). Imaging mass spectrometry of natural products. Nat Prod Rep 26: 1521-1534.

Gasper GL, Carlson R, Akhmetov A, Moore JF, Hanley L (2008) Laser desorption $7.87 \mathrm{eV}$ postionization mass spectrometry of antibiotics in Staphylococcus epidermidis bacterial biofilms. Proteomics 8: 3816-3821.

Girgis M (2003) Potassium and anaesthesia. Update Anaesth 17: 1 .

Ghosal S, Fallon SJ, Leighton TJ, Wheeler KE, Kristo MJ, Hutcheon ID, Weber PK (2008) Imaging and 3D elemental characterization of intact bacterial spores by high resolution secondary ion mass spectrometry. Anal Chem 80: 5986-5992.

Goto T, Brunette DM (1998) Surface topography and serum concentration affect the appearance of tenascin in human gingival fibroblasts in vitro. Exp Cell Res 244: 474-480.

Gristina AG (1987) Biomaterial-centered infection: microbial adhesion versus tissue integration. Science 237: 1588-1595.

Gristina AG, Costerton JW (1985) Bacterial adherence to biomaterials and tissue. The significance of its role in clinical sepsis. J Bone Joint Surg Am 67: 264-273.

Henry M, Bertrand P (2009) Surface composition of insulin and albumin adsorbed on polymer substrates as revealed by multivariate analysis of ToF-SIMS data. Surf Interface Anal 41: 105-113.

Jungnickel H, Jones EA, Lockyer NP, Oliver SG, Stephens GM, Vickerman JC (2005) Application of TOFSIMS with chemometrics to discriminate between four different yeast strains from the species Candida glabrata and Saccharomyces cerevisiae. Anal Chem 77: 1740-1745.

Kaivosoja E, Barreto G, Levón K, Virtanen S, Ainola M, Konttinen YT (2011) Chemical and physical properties of regenerative medicine materials controlling stem cell fate. Ann Med, in press.

Killian MS, Krebs HM, Schmuki P (2011) Protein denaturation detected by time-of-flight secondary ion mass spectrometry. Langmuir 27: 7510-7515.

Konttinen YT, Kaivosoja E, Stegaev V, Wagner HD, Levón J, Tiainen V-M, Mackiewicz Z (2011) Extracellular matrix and tissue regeneration. In: Steinhoff G (ed) Regenerative Medicine - from Protocol to Patient. Springer, London, pp 21-80.

Kulp KS, Berman ESF, Knize MG, Shattuck DL, Nelson EJ, Wu L, Montgomery JL, Felton JS, Wu KJ (2006) Chemical and biological differentiation of three human breast cancer cell types using time-of-flight secondary ion mass spectrometry. Anal Chem 78: 36513658 .

Levon J, Myllymaa K, Kouri V-P, Rautemaa R, Kinnari T, Myllymaa S, Konttinen YT, Lappalainen R (2010) Patterned macroarray plates in comparison of bacterial adhesion inhibition of tantalum, titanium, and chromium compared with diamond-like carbon. J Biomed Mater Res A 92: 1606-1613.

Lhoest JB, Wagner MS, Tidwell CD, Castner DG (2001) Characterization of adsorbed protein films by time of flight secondary ion mass spectrometry. J Biomed Mater Res 57: 432-440. 
Marculescu CE, Berbari EF, Hanssen AD, Steckelberg JM, Osmon RD (2005) Prosthetic joint infection diagnosed postoperatively by intraoperative culture. Clin Orthop Relat Res 439: 38-42.

Malekzadeh D, Osmon DR, Lahr BD, Hanssen AD, Berbari EF (2010) Prior use of antimicrobial therapy is a risk factor for culture-negative prosthetic joint infection. Clin Orthop Relat Res 468: 2039-2045.

Mustafa K, Pan J, Wroblewski J, Leygraf C, Arvidson K (2002) Electrochemical impedance spectroscopy and X-ray photoelectron spectroscopy analysis of titanium surfaces cultured with osteoblast-like cells derived from human mandibular bone. J Biomed Mater Res 59: 655-664.

Myllymaa K, Myllymaa S, Korhonen H, Tiitu V, Lammi M, Lappalainen R (2009) Interactions between SaOS-2 cells and microtextured amorphous diamond or amorphous diamond hybrid coated surfaces with different wettability properties. Diam Relat Mater 18: 1294-1300.

Myllymaa S, Kaivosoja E, Myllymaa K, Sillat T, Korhonen H, Lappalainen R, Konttinen YT (2010) Adhesion, spreading and osteogenic differentiation of mesenchymal stem cells cultured on micropatterned amorphous diamond, titanium, tantalum and chromium coatings on silicon. J Mater Sci Mater Med 21: 329-341.

Neut D, van Horn JR, van Kooten TG, van der Mei HC, Busscher HJ (2003) Detection of biomaterial-associated infections in orthopaedic joint implants. Clin Orthop Relat Res 413: 261-268.

Page K, Wilson M, Parkin IP (2009) Antimicrobial surfaces and their potential in reducing the role of the inanimate environment in the incidence of hospitalacquired infections. J Mater Chem 19: 3819-3831

Panousis K, Grigoris P, Butcher I, Rana B, Reilly JH, Hamblen DL (2005) Poor predictive value of broad-range PCR for the detection of arthroplasty infection in 92 cases. Acta Orthop 76: 341-346.

Saldarriaga Fernández IC, Da Silva Domingues JF, van Kooten TG, Metzger S, Grainger DW, Busscher HJ, van der Mei HC (2011a) Macrophage response to staphylococcal biofilms on crosslinked poly(ethylene) glycol polymer coatings and common biomaterials in vitro. Eur Cell Mater 21: 73-79.

Saldarriaga Fernández IC, Busscher HJ, Metzger SW, Grainger DW, van der Mei HC (2011b) Competitive time- and density-dependent adhesion of staphylococci and osteoblasts on crosslinked poly(ethylene glycol)based polymer coatings in co-culture flow chambers. Biomaterials 32: 979-984

Samuel NT, Wagner MS, Dornfeld KD, Castner DG (2001) Analysis of poly-amino acids by static time-of-flight secondary ion mass spectrometry TOF-SIMS. Surface Science Spectra 8: 163-184.

Santavirta S, Gristina AG, Konttinen YT (1992) Cemented versus cementless hip arthroplasty. A review of prosthetic biocompatibility. Acta Orthop Scand 63: 225232.

Shin YN, Kim BS, Ahn HH, Lee JH, Kim KS, Lee JY, Kim MS, Khang G, Lee HB (2008) Adhesion comparison of human bone marrow stem cells on a gradient wettable surface prepared by corona treatment. Appl Surf Sci 255: 293-296.

Sohail MR, Uslan DZ, Khan AH, Friedman PA, Hayes DL, Wilson WR, Steckelberg JM, Stoner S, Baddour LM (2007) Management and outcome of permanent pacemaker and implantable cardioverterdefibrillator infections. J Am Coll Cardiol 49: 1851-1859.

Stevens JS, Schroeder SLM (2009) Quantitative analysis of saccharides by X-ray photoelectron spectroscopy. Surf Interface Anal 41:453-462.

Trampuz A, Widmer AF (2006) Infections associated with orthopedic implants. Curr Opin Infect Dis 19: 349356.

Trampuz A, Zimmerli W (2006) Diagnosis and treatment of infections associated with fracture-fixation devices. Injury 37:S59-S66.

Tunney MM, Patrick S, Curran MD, Ramage G, Hanna D, Nixon JR, Gorman SP, Davis RI, Anderson N (1999) Detection of prosthetic hip infection at revision arthroplasty by immunofluorescence microscopy and PCR amplification of the bacterial 16S rRNA gene. J Clin Microbiol 37: 3281-3290.

Tyler BJ, Rangaranjan S, Möller J, Beumer A, Arlinghaus HF (2006) TOF-SIMS imaging of chlorhexidinedigluconate transport in frozen hydrated biofilms of the fungus Candida albicans. Appl Surf Sci 252: 6712-6715.

Valle J, Toledo-Arana A, Berasain C, Ghigo JM, Amorena B, Penades JR, Lasa I (2003) SarA and not sigmaB is essential for biofilm development by Staphylococcus aureus. Mol Microbiol 48: 1075-1087.

Wagner MS, Castner DG (2001) Characterization of adsorbed protein films by time-of-flight secondary ion mass spectrometry with principal component analysis. Langmuir 17: 4649-4660.

Wagner MS, McArthur SL, Shen M, Horbett TA, Castner DG (2002a) Limits of detection for time of flight secondary ion mass spectrometry (ToF-SIMS) and X-ray photoelectron spectroscopy (XPS): detection of low amounts of adsorbed protein. J Biomater Sci Polym Ed 13: 407-428.

Wagner MS, Tyler BJ, Castner DG (2002b) Interpretation of static time-of-flight secondary ion mass spectra of adsorbed protein films by multivariate pattern recognition. Anal Chem 74: 1824-1835.

Wagner MS, Horbett TA, Castner DG (2003a) Characterizing multicomponent adsorbed protein films using electron spectroscopy for chemical analysis, time-offlight secondary ion mass spectrometry, and radiolabeling: capabilities and limitations. Biomaterials 24: 1897-1908.

Wagner MS, Shen M, Horbett TA, Castner DG (2003b) Quantitative analysis of binary adsorbed protein films by time of flight secondary ion mass spectrometry. J Biomed Mater Res A 64: 1-11.

Xia N, May CJ, McArthur SL, Castner DG (2002) Time-of-flight secondary ion mass spectrometry analysis of conformational changes in adsorbed protein films. Langmuir 18: 4090-4097.

Zimmerli W (2006) Infection and musculoskeletal conditions: Prosthetic-joint-associated infections. Best Pract Res Clin Rheumatol 20: 1045-1063. 


\section{Discussion with Reviewers}

Reviewer I: Can you give some ideas how to solve/treat this problems/diagnosis which are more present today than for 30 years ago?

Authors: To be able to create better implants and biomaterials it is critical to understand the reasons for failure. ToF-SIMS may provide less false negative and false positive results than currently used methods to detect implant-related deep infections and could thus provide accurate information even in antibiotic treated cases. Secondly, this approach could be used for in vitro testing of new implant coatings to indicate how well they are able to resist bacterial adhesion and production of extracellular polymeric matrix (biofilm, bacterial slime).

Reviewer II: What is your opinion about the practicality of doing such an analysis routinely, i.e. are these expensive pieces of equipment requiring specialists to use them?

Authors: When the differences between footprints of the host cells and bacteria have been clarified, specific components of the footprint might be identified with other less expensive methods, even in routine clinical use. We believe that, at present, this technique is most relevant for research and development of new biomaterials and coatings and is too expensive for routine clinical use.

At least some cases of failed orthopaedic implants that were considered aseptic loosening, based on the absence of clinical signs of infection and the failure to isolate bacteria, may actually have an infectious etiology (Nelson et al., 2005, additional reference). The footprint analysis, done after the removal of the implant and demonstrating bacterial footprints, could then suggest septic loosening in retrospect, even in culture negative cases. This could have also clinical relevance for the follow-up of the revision operated patient, because a full clearance of the infection is considered to be important in the prevention of recurrent infections and such patients might have an increased risk of such a recurrence (Engelsman et al., 2010, additional reference). In particular, the exact reason for the implant failure is crucial for researchers and developers, who try to evaluate the true incidence of infections and to develop new biomaterials and coatings able to resist bacterial adherence and biofilm formation. Only by understanding the reasons of implant failures will we be able to create better implants in the future.

In addition, the analysis is relatively fast to perform. Of course, this technique, due to the relatively small size of the sample chamber, is not at present suitable for largesize implants, such as hip implants, but would be perfect for small implants, such as middle ear implants.

Reviewer II: Do you expect that this same technique will be able to detect other microorganisms, such as Staphylococcus epidermidis, Pseudomonas aeruginosa etc? Furthermore, do you expect that it would work in the presence of different types of eukaryotic cells such as osteoblasts, fibroblasts etc.?

Authors: We would expect that by using similar amino acid based segmentation, biofilm producing bacteria can be separated from eukaryotic cells, even if there are multiple different types of eukaryotic cells present. It could be even possible to detect the type of the micro-organism and cells, although that can be challenging from the footprint only.

Reviewer II: Why not select secreted protein peaks known to be unique to prokaryotes versus eukaryotes and use these as a basis for imaging contrast?

Authors: This could be an interesting approach. However, proteins that are adsorbed on the surface do not represent exactly the composition of proteins in the bulk solution. Generally speaking, the proteins that have the greatest mobility are adsorbed first and are later replaced by proteins that have a higher affinity for surface. Proteinsurface interactions result in high local concentrations of the protein, reaching concentrations up to 1000 times higher than in the bulk solution. Respectively, some proteins strongly expressed in the bulk solution, might not be present at the surface at all. Therefore, components, which in the preliminary analysis of the ToF-SIMS spectra showed difference between MSC and S. aureus samples, were selected for imaging.

Reviewer II: What influence does co-culture medium have on the matrix production of each cell type?

Authors: The co-culture media did not influence the amount of EPS production by $S$. aureus. However, coculture stress could lead to stressed phenotypes of the cultured cells and deposition of stress-related matrix proteins on the surface of the culture substrate, which could affect cellular adhesion.

Reviewer II: Is linear subtraction of ToF-SIMS peak sets appropriate, given their non-linear intensity correlations from many different matrix effects specific to each ion fragment?

Authors: With the background subtraction we used, it was possible to reduce the effect of the different media used (MSCGM or TSB). Peaks that can originate from several different amino acids (marked with a star in Table 1) were not included in the analysis and therefore, linear subtraction is a relatively good approximation. However, in general, the relationship of the background to the ToF-SIMS peaks is far from simple and some more sophisticated method could give a better approximation for the background. Nonetheless, even when we tested the separation of MSC samples and co-culture samples (both cultured in MSCGM) without any subtraction, it was possible to separate the samples.

\section{Additional References}

Engelsman AF, Saldarriaga-Fernandez IC, Nejadnik MR, van Dam GM, Francis KP, Ploeg RJ, Busscher HJ, van der Mei HC (2010) The risk of biomaterial-associated infection after revision surgery due to an experimental primary implant infection. Biofouling 26: 761-767.

Nelson CL, McLaren AC, McLaren SG, Johnson JW, Smeltzer MS (2005) Is aseptic loosening truly aseptic? Clin Orthop Relat Res 437: 25-30. 